\title{
Trichorhinophalangeal syndrome
}

\begin{abstract}
We describe a trichorhinophalangeal syndrome in a 9 year-old female, showing thinning hair, rarefaction of the lateral eyebrow, pear-shaped nose, long and flat philtrum, thin upper lip, receding chin, short stature and brachydactyly. In spite of being rare, trichorhinophalangeal syndrome may be more frequent than postulate in the literature, since less expressive phenotype cases may be more difficult to diagnose. Therefore, knowledge of this condition becomes important to allow a proper genetic counseling and follow-up.
\end{abstract}

Keywords: brachydactyly, alopecia, hair, scalp, syndrome
Volume 2 Issue I - 2018

Rogério Nabor Kondo,' Mariana Onuki Okamura, ${ }^{2}$ Vanessa Ghen, ${ }^{2}$ Priscila Daiane Pavezzi, ${ }^{2}$ Francine Milenkovich Belinetti, ${ }^{2}$ Fernanda Teixeira Ortega ${ }^{2}$

'Assistant Professor of dermatology, Hospital Universitário Regional do Norte do Paraná, Brazil

${ }^{2}$ Resident of Dermatology, Hospital Universitário Regional do Norte do Paraná, Brazil

Correspondence: Rogério Nabor Kondo MD, Dermatologist, Assistant professor of dermatology, Hospital Universitário Regional do Norte do Paraná, State University of Londrina, Paraná , Brazil, Email kondo.dermato@gmail.com

Received: December 10, 2017 | Published: February 14, 2018

\section{Case report}

FEMALE patient, 9 years old, with thin, non-growing hair. It presents diffuse rarefaction of the hair, with a pattern of non-cicatricial alopecia, fine and short hair, rarefaction of the distal third of the eyebrow, bulbous nose and enlargement of the nasolabial filter, fine upper lip, micrognathism, short stature, brachydactyly, curved feet and shortening of some metacarpals (Figure 1) (Figure 2). Intellectual development was normal and absence of similar cases in the family.
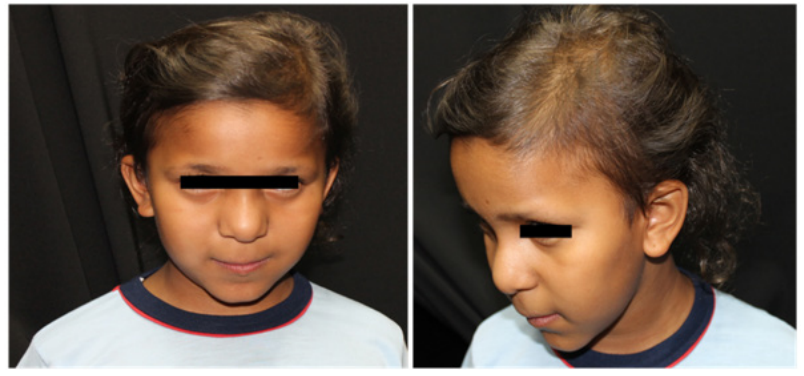

Figure I Non scarring hair loss, fine and short hair, rarefaction of the distal third of the eyebrow, bulbous nose and enlargement of the nasolabial filter, fine upper lip, micrognathism.
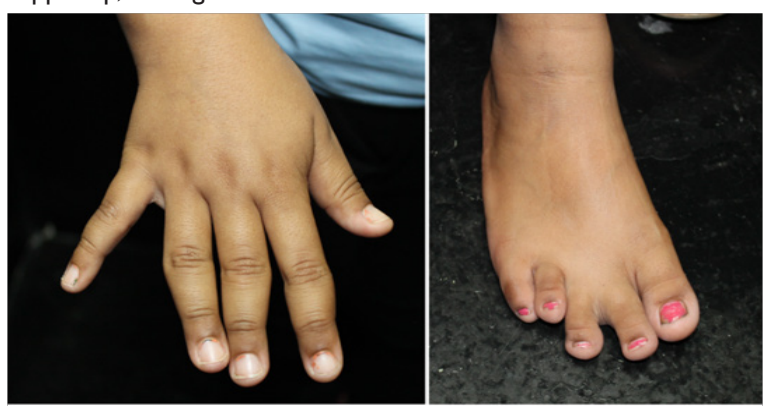

Figure 2 Brachydactyly, curved feet and shortening of some metacarpals and metatarsals.
The laboratory tests requested were hemogram, electrolytes, albumin, glycemia, thyrotrophic hormone, parathyroid hormone, vitamin D and zinc; all normal. Radiographs showed bone changes of the phalanges, with cone-shaped epiphyses (Figure 3) and advanced bone age in 2 years. Trichogram with $44 \%$ anagen, $53 \%$ telogen, $1 \%$ catagen and $2 \%$ dystrophic anagen.

Hystopathology with rarefied pilo-sebaceous follicles, most of the bulbs anchored in the subcutaneous tissue, besides some smaller diameter follicles in the dermis (Figure 4).

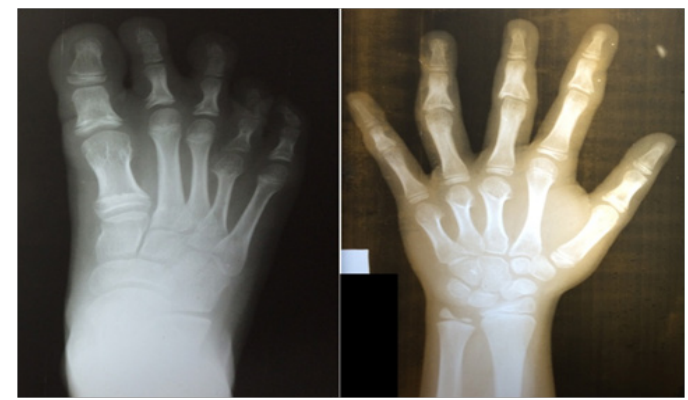

Figure 3 Radiographs showed bone changes of the phalanges, with coneshaped epiphyses.

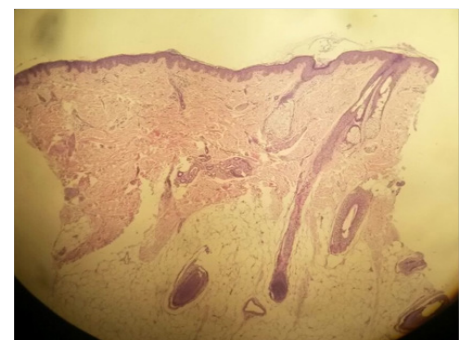

Figure 4 Hystopathology with rarefied pilo-sebaceous follicles, most of the bulbs anchored in the subcutaneous tissue, besides some smaller diameter follicles in the dermis. 


\section{Discussion}

Giedion, in 1966, was the first to describe the trichorhinophalangeal syndrome (TRPS) and to propose the denomination that persists to the present. Three variants are classified, classified as TRPS type I, characterized clinically by the association of fine, sparse and slowgrowing hairs, pear-shaped nose, elongated filter, thin upper lip and bone alterations, particularly cone-shaped epiphyses in the fingers (distinctive feature of the syndrome). ${ }^{1-5}$ TRPS type II, which is associated with microcephaly and mental retardation, cartilaginous exostoses and others more severe osteoarticular manifestations; and TRPS type III, a type I proximal variant, which is phenotypically differentiated by the accentuation of shortening of the phalanges, metacarpals and metatarsals, and of short stature. ${ }^{2}$ Other phenotypic alterations may be associated and are described in Table 1 .

Table I Phenotypic alterations associated with TRPS

\begin{tabular}{|c|c|c|}
\hline $\begin{array}{l}\text { Trichorhinophalangeal syndrome } \\
\text { type I }\end{array}$ & $\begin{array}{l}\text { Trichorhinophalangeal } \\
\text { syndrome type II (Langer- } \\
\text { Giedion) }\end{array}$ & $\begin{array}{l}\text { Trichorhinophalangeal syndrome } \\
\text { type III (Sugio-Kajii) }\end{array}$ \\
\hline Sparse and fragile scalp hair & Sparse scalp hair & Same characteristics of type I \\
\hline Pilli torti & Prominent pear-shaped nose & Accentuation of short stature \\
\hline Ticorrexe nodosa & $\begin{array}{l}\text { Pear-shaped phalangeal } \\
\text { epiphyses (x-rays) }\end{array}$ & $\begin{array}{l}\text { Increased sharp shortening of the } \\
\text { phalanges, metacarpals and metatarsals }\end{array}$ \\
\hline Prominent pear-shaped nose & Multiple exostoses & \\
\hline Broad and raised nasal bridge & Prominent ears & \\
\hline $\begin{array}{l}\text { Pear-shaped phalangeal epiphyses } \\
\text { (x-rays) }\end{array}$ & Microcephaly & \\
\hline Curved fingers and toes & Short stature & \\
\hline Brachydactyly & Hyperextensible joints & \\
\hline Brittle and thin nails & Redundant skin in childhood & \\
\hline Short stature & Increased number of nevi & \\
\hline Winged scapulae & Mental retardation & \\
\hline $\begin{array}{l}\text { Deep voice } \\
\text { Degenerative diseases of the hips in } \\
\text { youth }\end{array}$ & & \\
\hline
\end{tabular}

Diagnosis should be suspected through the presence of specific clinical features of the syndrome, and may be confirmed by clinical evaluation, detailed history and radiological study. Analysis of molecular genetics may demonstrate mutations of the TRPS1 gene, located on the long arm of chromosome 8 (8q24.1). ${ }^{1,2}$ Our case is classified as type 1 , considering that there is no accentuation of shortening of all phalanges, metacarpals and metatarsals, nor of short stature.

Of the possible clinical alterations observed in the TRPS-I, alopecia may be the most frequent complaint. ${ }^{2}$ Findings of the trichogram are not homogeneous, with some studies demonstrating pattern of androgenetic alopecia combined with diffuse alopecia and others with no definite pattern. ${ }^{2}$ Some studies also mention advanced bone age in radiological investigation.

Histopathology shows a reduction in the number of follicles, with the majority of bulbs anchored in the subcutaneous tissue, in addition to smaller diameter anagen and absence of inflammatory infiltrate. ${ }^{1}$

Differential diagnosis of TRPS-I is made with the other variants of the syndrome itself, with androgenetic alopecia of early onset (in the milder phenotypes) and with others that include alopecia and structural abnormalities of the nose or osteoarticular abnormalities.

\section{Conclusion}

The treatment is symptomatic and directed to the symptoms of each individual affected. ${ }^{1}$ Although considered to be rare (with a prevalence of $0.2-1$ per 100,000$),{ }^{6}$ it is postulated that TRPS is more frequent than has been described, since less expressive phenotypes may go unnoticed. Therefore, knowledge of the syndrome is important in order to initiate adequate genetic counseling and follow-up. ${ }^{2}$

\section{Acknowledgements}

None.

\section{Conflicts of interest}

The author decalres no conflict of interest.

\section{References}

1. Araujo IB, Scherrer MAR, Carmo CA. Síndrome trico-rino-falangiana. An Bras Dermatol. 1983;58(5):215-218.

2. Marques SA, Miot HA, Miot LDB, et al.Você conhece esta síndrome? An Bras Dermatol. 2005;80(1):85-88.

3. Dias C, Isidoro L, Santos M, et al. Case Report Trichorhinophalangeal Syndrome Type I: A patient with two novel and different mutations in the TRPS I gene. Case Rep Genet. 2013;2013:Article ID 748057.

4. Maas SM, Shaw AC, Bikker H, et al. Phenotype and genotype in 103 patients with Tricho-Rhino-phalangeal syndrome. Eur J Med Genet. 2015;58(5):279-292.

5. De Barros GM, Kakehasi AM. Skeletal abnormalities of tricho-rhinophalangeal syndrome type I. Rev Bras Reumatol Engl Ed. 2014;56(1):8689.

6. Maas S, Shaw A, Bikker H, et al. Trichorhinophalangeal Syndrome. In: Pagon RA, et al, editors. GeneReviwes®. USA; 2017. 